Check for updates

Cite this: Chem. Sci., 2019, 10, 6304

๑ All publication charges for this article have been paid for by the Royal Society of Chemistry

Received 2nd February 2019

Accepted 8th May 2019

DOI: $10.1039 / \mathrm{c} 9 \mathrm{sc} 00605 \mathrm{~b}$

rsc.li/chemical-science

\title{
Diiron oxo reactivity in a weak-field environment $+\$$
}

\author{
Elizabeth J. Johnson, (D) $\$$ Claudia Kleinlein, $\$$ Rebecca A. Musgrave (iD \\ and Theodore A. Betley (D) *
}

Concomitant deprotonation and metalation of a dinucleating cofacial Pacman dipyrrin ligand platform ${ }^{t B u} \mathrm{dmxH} \mathrm{H}_{2}$ with $\mathrm{Fe}_{2}(\mathrm{Mes})_{4}$ results in formation of a diiron complex $\left({ }^{\mathrm{tBu}} \mathrm{dmx}\right) \mathrm{Fe}_{2}(\mathrm{Mes})_{2}$. Treatment of $\left({ }^{\mathrm{BB} u} \mathrm{dmx}\right) \mathrm{Fe}_{2}(\mathrm{Mes})_{2}$ with one equivalent of water yields the diron $\mu$-oxo complex $\left({ }^{\mathrm{CBu}} \mathrm{dmx}\right) \mathrm{Fe}_{2}(\mu-O)$ and free mesitylene. A two-electron oxidation of $\left({ }^{\mathrm{B} u} \mathrm{dmx}\right) \mathrm{Fe}_{2}(\mu-O)$ gives rise to the diferric complex $\left({ }^{\mathrm{B} u} \mathrm{dmx}\right)$ $\mathrm{Fe}_{2}(\mu-\mathrm{O}) \mathrm{Cl}_{2}$, and one-electron reduction from this $\mathrm{Fe}^{\text {III }} \mathrm{Fe}{ }^{\text {III }}$ state allows for isolation of a mixed-valent

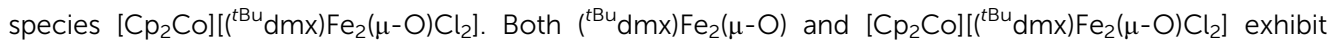
basic character at the bridging oxygen atom and can be protonated using weak acids to form bridging diferrous hydroxide species. The basicity of the diferrous oxo $\left({ }^{\mathrm{tBu}} \mathrm{dmx}\right) \mathrm{Fe}_{2}(\mu-O)$ is quantified through studies of the $\mathrm{p} K_{\mathrm{a}}$ of its conjugate acid, $\left[\left({ }^{\mathrm{tBu}} \mathrm{dmx}\right) \mathrm{Fe}_{2}(\mu-\mathrm{OH})\right]^{+}$, which is determined to be 15.3(6); interestingly, upon coordination of neutral solvent ligands to yield $\left({ }^{\mathrm{tBu}} \mathrm{dmx}\right) \mathrm{Fe}_{2}(\mu-\mathrm{O})(\mathrm{thf})_{2}$, the basicity is increased as observed through an increase in the $\mathrm{p} K_{\mathrm{a}}$ of the conjugate acid $\left.\left[{ }^{t \mathrm{Bu}} \mathrm{dmx}\right) \mathrm{Fe}_{2}(\mu-\mathrm{OH})(\mathrm{thf})_{2}\right]^{+}$to 26.8(6). In contrast, attempts to synthesize a diferric bridging hydroxide by two-electron oxidation of $\left[\left({ }^{t \mathrm{Bu}} \mathrm{dmx}\right) \mathrm{Fe}_{2}(\mu-\mathrm{OH})(\mathrm{thf})_{2}\right]^{+}$resulted in isolation of $\left({ }^{\mathrm{tBu}} \mathrm{dmx}\right) \mathrm{Fe}_{2}(\mu-\mathrm{O}) \mathrm{Cl}_{2}$ with concomitant loss of a proton, consistent with the $\mathrm{p} K_{\mathrm{a}}$ of the conjugate acid $\left[\left({ }^{\mathrm{tBu}} \mathrm{dmx}\right) \mathrm{Fe}_{2}(\mu-\mathrm{OH}) \mathrm{Cl}_{2}\right]^{+}$determined computationally to be $-1.8(6)$. The foregoing results highlight the intricate interplay between oxidation state and reactivity in diiron $\mu$-oxo units.

\section{Introduction}

Diiron units featuring bridging oxygen ligands are important structural motifs in metalloenzymes. ${ }^{1-4}$ For example, methane monooxygenase, ribonucleotide reductase, and hemerythrin feature diiron units which are responsible for oxygen activation or transport of dioxygen to a variety of substrates. ${ }^{5,6}$ During these processes, a diiron unit which is bridged by one or two oxygen-based ligands passes through oxidation states ranging from $\mathrm{Fe}^{\mathrm{II}} \mathrm{Fe}^{\mathrm{II}}$ to $\mathrm{Fe}^{\mathrm{IV}} \mathrm{Fe}^{\mathrm{IV}}$. Synthetic model complexes featuring a $\mu$-oxo or $\mu$-hydroxo bridge have been prepared in order to create functional mimics of these enzymes. ${ }^{7-9}$ In particular, the interconversion between hydroxo- and oxo-bridged states has been of interest as it is proposed to play an important role during the catalytic cycle of metalloenzymes. ${ }^{\mathbf{1 0 , 1 1}}$ While there are many synthetic examples of diferric Fe-O-Fe units, ${ }^{\mathbf{1 2}-18}$ few mixed-valent $\mathrm{Fe}^{\mathrm{II}}-\mathrm{O}-\mathrm{Fe}^{\mathrm{III}}$ complexes and $\mathrm{Fe}^{\mathrm{II}}-\mathrm{O}-\mathrm{Fe}^{\mathrm{II}}$ complexes have been reported. ${ }^{\mathbf{1 9 - 2 2}}$ In contrast, a variety of model complexes for both diferric and diferrous hydroxides have been synthesized., ${ }^{9,23,24}$

Department of Chemistry and Chemical Biology, Harvard University, Cambridge, MA 02138, USA. E-mail: betley@chemistry.harvard.edu

$\dagger$ Electronic supplementary information (ESI) available. CCDC 1554783-1554789. For ESI and crystallographic data in CIF or other electronic format see DOI: 10.1039/c9sc00605b

\$ Authors contributed equally.
To better understand how the molecular oxidation state of a diiron core influences the acid-base properties of a bridging (hydr)oxo ligand, we explored the coordination and redox chemistry of a diiron unit in a cofacial dipyrrin Pacman unit. Herein, we report the synthesis and versatile reactivity of a family of diiron oxo and hydroxo complexes in three different molecular oxidation states. Reactions include acid-base chemistry as well as one and two electron redox chemistry, which demonstrate the intricate interplay between oxidation state, coordination environment, and reactivity.

\section{Results and discussion}

\section{Synthesis of a diiron starting material}

Formation of the diiron dipyrrin Pacman complex $\left({ }^{t \mathrm{Bu}} \mathrm{dmx}\right)$ $\mathrm{Fe}_{2}(\mathrm{Mes})_{2}$ (1) proceeds cleanly from the reaction of the cofacial dipyrrin Pacman ligand ${ }^{t \mathrm{Bu}} \mathrm{dmxH}_{2}$ with $\mathrm{Fe}_{2}(\mathrm{Mes})_{4}$ (Mes $=2,4,6-$ $\mathrm{Me}_{3} \mathrm{C}_{6} \mathrm{H}_{2}$ ) in benzene at $65{ }^{\circ} \mathrm{C}$ for four hours (Scheme 1). The composition and purity of $\mathbf{1}$ were established by ${ }^{1} \mathrm{H}$ NMR spectroscopy, ${ }^{57} \mathrm{Fe}$ Mössbauer spectroscopy, and combustion analysis. X-ray diffraction studies on a single crystal of 1 obtained from a toluene solution layered with hexanes at $-35{ }^{\circ} \mathrm{C}$ revealed two non-interacting iron sites residing in a trigonalplanar geometry (Fig. S-27†). ${ }^{57} \mathrm{Fe}$ Mössbauer analysis of 1 confirmed the presence of a single iron environment $(\delta=$ $0.46 \mathrm{~mm} \mathrm{~s}^{-1},\left|\Delta E_{\mathrm{Q}}\right|=0.95 \mathrm{~mm} \mathrm{~s}^{-1}$ ) in line with other high-spin $\mathrm{Fe}^{\mathrm{II}}$ complexes containing alkyl or aryl ligands (Fig. S-1†). ${ }^{25-27}$ 


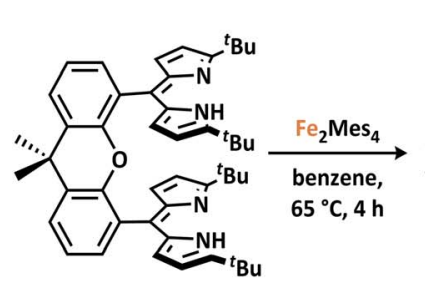

Scheme 1 Synthesis of $\left({ }^{\mathrm{tBu}} \mathrm{dmx}\right) \mathrm{Fe}_{2}(\mu-\mathrm{O})(3)$.

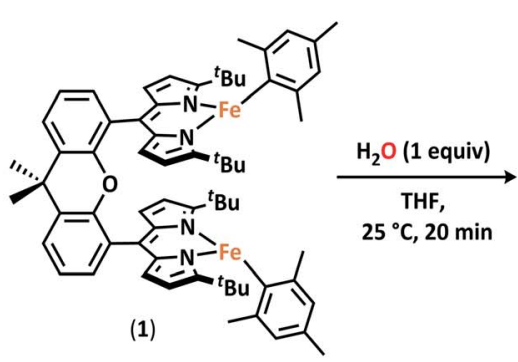

(1)

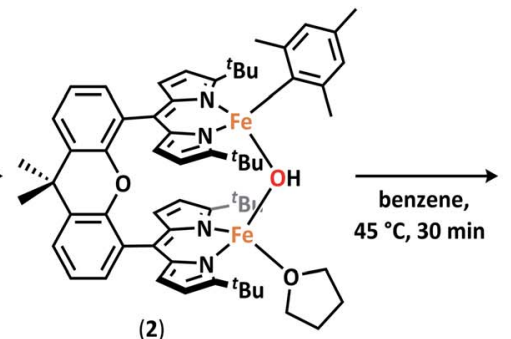

(2)

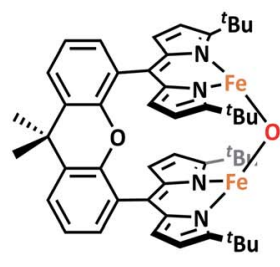

(3)
Magnetometry data was consistent with the presence of two uncoupled $S=2$ centers (Fig. $S-23 \dagger$ ).

\section{Isolation and characterization of a diferrous $\mu$-oxo}

Diiron complex $\mathbf{1}$ is a versatile starting material for the preparation of $\mu$-hydroxo and $\mu$-oxo diiron complexes. Addition of one equivalent of water to 1 results in complete consumption of the starting material and formation of a new, asymmetric species, as evidenced by the presence of 18 paramagnetically-shifted ${ }^{1} \mathrm{H}$ NMR resonances along with the formation of free mesitylene. ${ }^{28}$ Cooling a concentrated diethyl ether solution of this product to $-35{ }^{\circ} \mathrm{C}$ affords an orange crystalline material which was characterized by X-ray diffraction to unveil an asymmetric Pacman complex $\left({ }^{t \mathrm{Bu}} \mathrm{dmx}\right) \mathrm{Fe}_{2}(\mu-\mathrm{OH})(\mathrm{Mes})($ thf $)(2)$ featuring a bridging hydroxide ligand (Scheme 1). One iron site remains bound to a mesitylene ligand with an Fe-O bond length of 2.045(3) $\AA$ while the second iron center is coordinated by a THF solvent molecule and exhibits a shorter Fe-O bond of 1.942(4) A (Fig. S$28 \dagger)$. The asymmetric nature of this complex is furthermore reflected by the ${ }^{57} \mathrm{Fe}$ Mössbauer spectrum, which contains two quadrupole doublets $\left(\delta=0.80 \mathrm{~mm} \mathrm{~s}^{-1},\left|\Delta E_{\mathrm{Q}}\right|=3.23 \mathrm{~mm} \mathrm{~s}^{-1}\right.$ and $\delta=0.99 \mathrm{~mm} \mathrm{~s}^{-1},\left|\Delta E_{\mathrm{Q}}\right|=2.92 \mathrm{~mm} \mathrm{~s}^{-1}$ ) (Fig. S-2†). Solidstate Fourier-transform infrared (FTIR) spectra of 2 were collected to further confirm the identity of the bridging ligand as a $\mu$-hydroxide (Fig. S-12†). Spectra of 2 show an $\mathrm{O}-\mathrm{H}$ stretching band at $3638 \mathrm{~cm}^{-1}$ that shifts to $2685 \mathrm{~cm}^{-1}$ when $\mathrm{D}_{2} \mathrm{O}$ is used to prepare the analogous deuterated bridging hydroxide complex $\left({ }^{t \mathrm{Bu}} \mathrm{dmx}\right) \mathrm{Fe}_{2}(\mu-\mathrm{OD})(\mathrm{Mes})(\mathrm{thf})$.
While 2 is stable in ethereal solvents at room temperature, slow deprotonation of the bridging hydroxide ligand concomitant with release of the second mesitylene molecule is observed in non-coordinating solvents. Heating of 2 in benzene to $45{ }^{\circ} \mathrm{C}$ for 30 minutes leads to complete consumption of starting material and furnishes a new product (3) which is easily discernible by ${ }^{1} \mathrm{H}$ NMR spectroscopy as a $C_{2}$-symmetric species distinct from the starting material (Scheme 1).

Zero-field ${ }^{57} \mathrm{Fe}$ Mössbauer analysis of 3 at $90 \mathrm{~K}$ (Fig. 2b, top) reveals the presence of a single iron environment with parameters $\left(\delta=0.68 \mathrm{~mm} \mathrm{~s}^{-1},\left|\Delta E_{\mathrm{Q}}\right|=0.88 \mathrm{~mm} \mathrm{~s}^{-1}\right)$ similar to other three-coordinate $\mathrm{Fe}^{\mathrm{II}}$ dipyrrin complexes previously synthesized. ${ }^{29}$ The ${ }^{57}$ Fe Mössbauer spectrum contains 5\% of an additional species with parameters corresponding to a fourcoordinate high-spin $\mathrm{Fe}^{\mathrm{II}}$ compound which we assign as a small amount of an unknown bridging hydroxide species. An $\mathrm{X}$-ray diffraction study on single crystals grown from a concentrated diethyl ether solution revealed the major product 3 as a diiron complex bearing a bridging oxido ligand, $\left({ }^{t \mathrm{Bu}} \mathrm{dmx}\right)$ $\mathrm{Fe}_{2}(\mu-\mathrm{O})$ (Fig. 1a). A crystallographically imposed $C_{2}$ axis renders the two halves of the complex equivalent. The Fe-O (1.7939(14) $\AA$ ) bond length is substantially shorter than the Fe-O distances in 2 (2.045(3) $\AA$, 1.942(4) $\mathrm{A}$ ) and in other $\mathrm{Fe}^{\mathrm{II}}$ hydroxides, and is in line with previously reported diferrous $\mu$-oxo species $[\mathrm{LFe}]_{2} \mathrm{O}$ (Fe-O 1.7503(4) $\mathrm{A}, \mathrm{L}=\operatorname{ArNC}\left({ }^{t} \mathrm{Bu}\right) \mathrm{CHC}\left({ }^{t} \mathrm{Bu}\right) \mathrm{NAr}^{-}$, where $\mathrm{Ar}=2$,6diisopropylphenyl; ${ }^{22}$ 1.784(9) $\AA, \mathrm{L}=\mathrm{PhBP}_{3}{ }^{\mathrm{iPr}} ;^{21}$ 1.753(2) $\AA \mathrm{\circ}, \mathrm{L}=$ $\mathrm{PhBP}_{3}{ }^{\mathrm{Ph}}$ (ref. 21)). The Fe-O-Fe angle in 3 (116.00(14) ${ }^{\circ}$ ) deviates significantly from linearity, which is more acute than previously

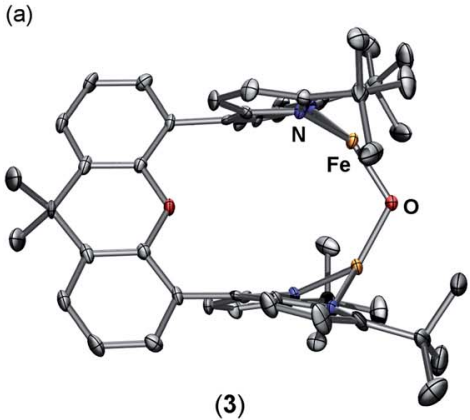

(3)

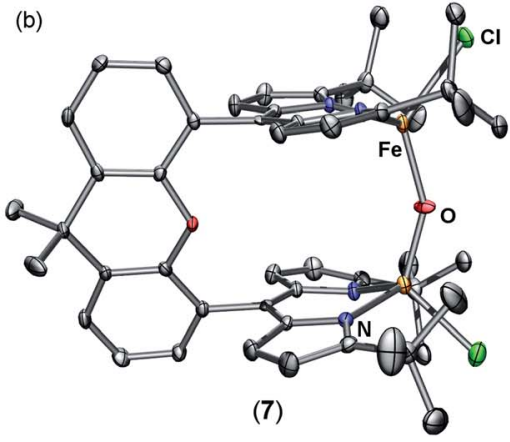

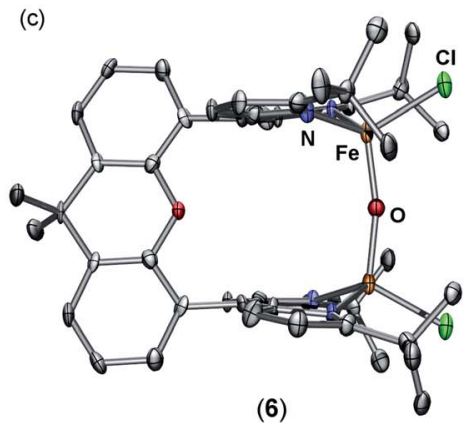

(6)

Fig. 1 Solid-state molecular structures for (a) $\left.{ }^{\mathrm{tBu}} \mathrm{dmx}\right) \mathrm{Fe}_{2}(\mu-\mathrm{O})(3)$, (b) $\left.\left[\mathrm{Cp}_{2} \mathrm{Co}\right]\left[{ }^{(\mathrm{Bu}} \mathrm{dmx}\right) \mathrm{Fe}_{2}(\mu-O) \mathrm{Cl}_{2}\right](7)$, and (c) $\left.{ }^{t \mathrm{Bu}} \mathrm{dmx}\right) \mathrm{Fe}_{2}(\mu-O) \mathrm{Cl}_{2}(6)$ with thermal ellipsoids at $50 \%$ probability level. Color scheme: Fe, orange; $\mathrm{N}$, blue; $\mathrm{O}$, red; $\mathrm{Cl}$, green. Hydrogens, solvent molecules, and counterion in 7 are omitted for clarity. 
reported diferrous oxo complexes $\left(\angle \mathrm{Fe}-\mathrm{O}-\mathrm{Fe} 167.55(14)^{\circ}, \mathrm{L}=\right.$ $\operatorname{ArNC}\left({ }^{t} \mathrm{Bu}\right) \mathrm{CHC}\left({ }^{t} \mathrm{Bu}\right) \mathrm{NAr}^{-} ;^{22}$ 174.7(4) ${ }^{\circ}, \mathrm{L}=\mathrm{PhBP}_{3}{ }^{{ }^{\mathrm{Pr}}}{ }^{21}{ }^{21} 147.7(3)^{\circ}, \mathrm{L}$ $=\mathrm{PhBP}_{3}{ }^{\mathrm{Ph}}$ (ref. 21)). The more acute $\mathrm{Fe}-\mathrm{O}-\mathrm{Fe}$ angle can be attributed to the restraints on the coordination chemistry imposed by the dinucleating ligand platform in 3 .

\section{Reactivity and basicity of the diferrous $\mu$-oxo}

With 3 in hand, we began examining its reactivity profile. Treatment of 3 with one equivalent of a weak acid such as lutidinium tetraphenylborate in THF results in quantitative formation of a diiron $\mu$-hydroxide cation $\left[\left({ }^{t \mathrm{Bu}} \mathrm{dmx}\right) \mathrm{Fe}_{2}(\mu-\mathrm{OH})\left(\mathrm{thf}_{2}\right)_{2}\right]\left[\mathrm{BPh}_{4}\right]$ (4) (Scheme 2). Given the observed reactivity of 3 with acids, we sought to quantify the basicity of 3 by establishing the $\mathrm{p} K_{\mathrm{a}}$ value of its conjugate acid. Following the precedent set by Smith et al., we attempted to use a combined approach of experiment and calculation to justify the reactivity of 3 with various weak acids. ${ }^{30}$ Due to the limited solubility of $\mathbf{3}$ and many of the suitable acids in non-coordinating solvents, we selected THF as the solvent for this study. Experimentally probing the protonation of 3 proved to be challenging, as the anticipated conjugate acid product, $\left[\left({ }^{t \mathrm{Bu}} \mathrm{dmx}\right)\right.$ $\left.\mathrm{Fe}_{2}(\mu-\mathrm{OH})\right]^{+}(\mathbf{4 a})$, is not stable to reaction conditions, as in many cases it reacts with the generated conjugate base, leading to multiple species observed by ${ }^{1} \mathrm{H}$ NMR spectroscopy. Consequently, efforts focused on replicating the theoretical procedure used by Smith et al. to computationally determine the $\mathrm{p} K_{\mathrm{a}}$ value of 4a. Using density functional theory (see ESI for details $\dagger$ ), the acidbase reaction shown in Scheme 3 was considered, in which HA is a weak acid with reported $\mathrm{p} K_{\mathrm{a}}$ value in $\mathrm{THF} .{ }^{31}$

Since these reactions were performed in THF, we examined the stability of 3 under these reaction conditions and discovered that solvents can bind the open coordination site at each metal

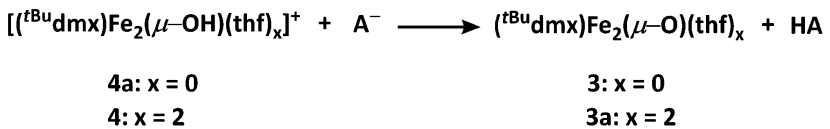

Scheme 3 General acid-base reaction studied.

center to begin to form $\left({ }^{t \mathrm{Bu}} \mathrm{dmx}\right) \mathrm{Fe}_{2}(\mu-\mathrm{O})(\text { thf })_{2}$ (3a) within minutes, as evidenced by ${ }^{57} \mathrm{Fe}$ Mössbauer spectroscopy (Fig. S$4 \dagger)$. Thus, we modelled the acid-base reaction for both 3 and for 3a (Scheme 3), the latter being the suspected active metal species during these reactions. The $\mathrm{p} K_{\mathrm{a}}$ value calculated for $\mathbf{4 a}$ (which is three-coordinate at iron) was 15.3(6), and upon coordination of two solvent molecules to form $\left[\left({ }^{t \mathrm{Bu}} \mathrm{dmx}\right) \mathrm{Fe}_{2}(\mu-\right.$ $\left.\mathrm{OH})(\text { thf })_{2}\right]^{+}$(4) increased to 26.8(6). We hypothesize that the coordination of a fourth ligand to each iron center results in the bridging oxo moiety adopting greater $\mathrm{O}^{2-}$ character, thus rendering the oxo ligand more basic. Computationally, we observe that the Fe-O covalency in 3a decreases upon addition of the solvent ligands to 3, reflected in a diminished Mayer bond $\operatorname{order}^{32,33}(3,0.811 ; 3 \mathbf{a}, 0.798)$, thus resulting in enhanced oxide character and basicity in 3a (Table S-6 $\dagger$ ). Several examples of metal oxo and nitrido complexes featuring enhanced reactivity upon coordination of additional neutral ligands $s^{34-36}$ or increased basicity due to coordination of anionic ligands ${ }^{37-40}$ have been studied. However, to our knowledge, no synthetic examples have been reported in which the change in basicity of a metal oxo species has been quantified upon coordination of neutral donors. In this case, we remarkably observe an increase in the basicity of a diiron bridging oxo complex by ten orders of magnitude upon coordination of the neutral donor THF.

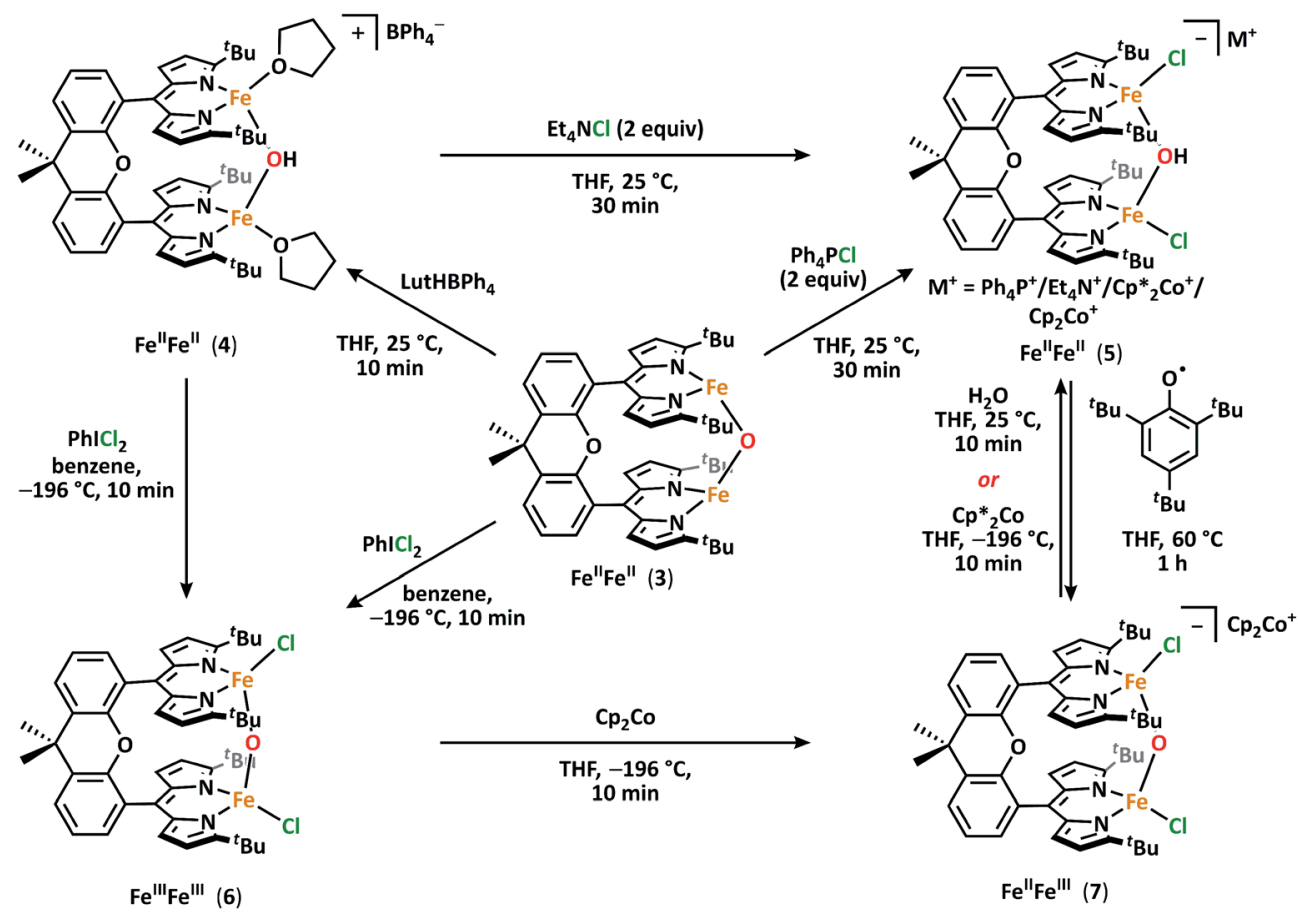

Scheme 2 Interconversion between diiron hydroxide and oxide species. 
To further demonstrate the basicity of these diiron(II) $\mu$-oxo complexes, we examined the reactivity of $\mathbf{3}$ upon coordination of anionic ligands. Stirring 3 in the presence of excess chloride sources such as tetraphenylphosphonium chloride in THF affords $\left[\mathrm{Ph}_{4} \mathrm{P}\right]\left[\left({ }^{t \mathrm{Bu}} \mathrm{dmx}\right) \mathrm{Fe}_{2}(\mu-\mathrm{OH}) \mathrm{Cl}_{2}\right](5 \mathrm{a})$ in high yield with no observable intermediates as ascertained by ${ }^{1} \mathrm{H}$ NMR (Scheme 2 ). The origin of the hydroxide proton in this product is unknown and protonation could not be prevented even in silylated glassware and freshly dried solvent. We propose that upon coordination of chloride ligands and formation of an anticipated dianionic iron complex, the basicity of the bridging oxo increases further, resulting in instantaneous protonation. Attempts to determine the $\mathrm{p} K_{\mathrm{a}}$ value of the $\left.\left[{ }^{\mathrm{tBu}} \mathrm{dmx}\right) \mathrm{Fe}_{2}(\mu-\mathrm{OH}) \mathrm{Cl}_{2}\right]^{-}$(the conjugate acid of the anticipated dianionic complex $\left.\left.\left[{ }^{\mathrm{tBu}} \mathrm{dmx}\right) \mathrm{Fe}_{2}(\mu-\mathrm{O}) \mathrm{Cl}_{2}\right]^{2-}\right)$ were not successful; however, based on the observed reactivity we hypothesize that this species would be more basic than $3 \mathbf{a}$ and thus feature a $\mathrm{p} K_{\mathrm{a}}>26.8$. The assignments of $\mathbf{4}$ and $\mathbf{5}$ as diiron $\mu$-hydroxides were confirmed by X-ray diffraction studies (Fig. 2a and S$32 \dagger),{ }^{57} \mathrm{Fe}$ Mössbauer spectroscopy (Fig. 2b, bottom; S-6†), and FTIR spectroscopy (Fig. S-14 and S-15†). One notable observation was that the $\mathrm{O}-\mathrm{H}\left(\nu=3548 \mathrm{~cm}^{-1}\right)$ and $\mathrm{O}-\mathrm{D}$ $\left(\nu=2587 \mathrm{~cm}^{-1}\right)$ frequencies for 4 and its deuterated analogue $\left[\left({ }^{t \mathrm{Bu}} \mathrm{dmx}\right) \mathrm{Fe}_{2}(\mu\right.$-OD $\left.)(\text { thf })_{2}\right]\left[\mathrm{BPh}_{4}\right]$ in the FTIR spectrum are lower than are often observed for such stretches ${ }^{29}$ which we hypothesize is due to a hydrogen-bonding interaction between the bridging hydroxide and a THF solvent molecule $\left(\mathrm{OH}-\mathrm{O}_{\mathrm{THF}}\right.$ $1.899(3) \AA)$, as observed in the solid-state. Magnetometry studies indicate that $\mathbf{4}$ features antiferromagnetic coupling of two $S=2$ iron centers with an exchange coupling $J=$ $-13.3 \mathrm{~cm}^{-1}$, which is in line with the expected values for diiron bridging hydroxide complexes (Fig. S-25†). ${ }^{10}$

\section{Oxidation of diferrous $\mu$-oxo}

Having established the basic nature of $\mathbf{3}$, we were interested in studying its redox chemistry. Particularly, we sought to address how the acid/base properties of the oxo complexes were influenced by the oxidation states of the metal centers. Addition of one equivalent of iodobenzene dichloride to 3 in benzene resulted in an immediate color change to dark red and a new paramagnetically shifted ${ }^{1} \mathrm{H}$ NMR spectrum. ${ }^{57} \mathrm{Fe}$ Mössbauer analysis of the reaction mixture revealed a single ironcontaining species with isomer shift and quadrupole splitting values supporting the assignment of high-spin $\mathrm{Fe}^{\mathrm{III}}(\delta=$ $0.30 \mathrm{~mm} \mathrm{~s}^{-1},\left|\Delta E_{\mathrm{Q}}\right|=1.38 \mathrm{~mm} \mathrm{~s}^{-1}$ ) indicating formation of $\left({ }^{t \mathrm{Bu}} \mathrm{dmx}\right) \mathrm{Fe}_{2}(\mu-\mathrm{O}) \mathrm{Cl}_{2}(6)$ (Fig. S-7†). Single crystals of 6 were grown by slow diffusion of diethyl ether into a saturated THF solution of 6 at $-35{ }^{\circ} \mathrm{C}$ (Fig. 1c). The solid state molecular structure of 6 features a crystallographically imposed $C_{2}$ axis that renders both iron sites equivalent. The iron-oxygen distance of 1.7734(10) $\AA$ is in agreement with the plethora of crystallographically characterized diferric $\mu$-oxo compounds, and the $\mathrm{Fe}-\mathrm{O}-\mathrm{Fe}$ angle of $167.1(3)^{\circ}$ only slightly deviates from linearity. ${ }^{41}$

Complex 6 can similarly be accessed by a two-electron oxidation of the diferrous hydroxide 4 using iodobenzene dichloride (Scheme 2). Oxidation of the hydroxide 4 does not furnish the anticipated cationic diferric bridging hydroxide species, rather the reaction product was spectroscopically identical to 6. Loss of the hydroxide proton in $\mathbf{4}$ was confirmed using IR spectroscopy. Unfortunately, we were not able to identify the fate of the proton in this reaction; however, the putative diferric bridging hydroxide intermediate $\left[\left({ }^{t \mathrm{Bu}} \mathrm{dmx}\right)\right.$ $\left.\mathrm{Fe}_{2}(\mu-\mathrm{OH}) \mathrm{Cl}_{2}\right]^{+}$(6a) was found to be quite acidic with a computationally determined $\mathrm{p} K_{\mathrm{a}}$ of $-1.8(6)$, which we propose is the driving force for facile loss of the proton concomitant with oxidation to the diferric state.

Herein, we observe a dramatic decrease in the basicity upon oxidation to the diferric state from a diferrous $\mu$-oxo. This trend can be explained by consideration of the Fe-O covalency, in which greater covalency results in decreased basicity of the bridging oxo. Increased covalency upon oxidation is supported

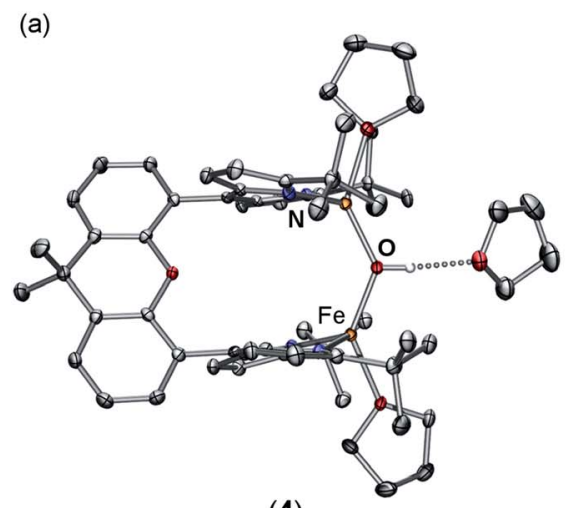

(4)

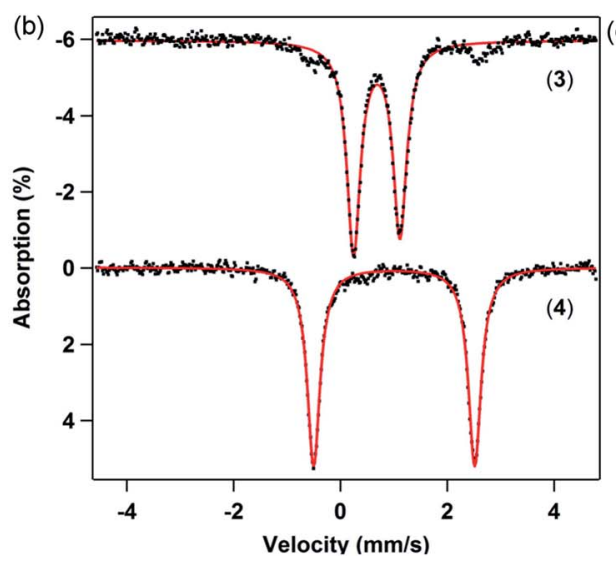

Fig. 2 (a) Solid-state molecular structure for $\left[\left({ }^{t B u} \mathrm{dmx}\right) \mathrm{Fe}_{2}(\mu-\mathrm{OH})(\mathrm{thf})_{2}\right]\left[\mathrm{BPh} \mathrm{h}_{4}\right](4)$ with thermal ellipsoids at $50 \%$ probability level. Color scheme: $\mathrm{Fe}$, orange; $\mathrm{N}$, blue; $\mathrm{O}$, red. All hydrogen atoms (except the $\mu$-hydroxo proton), solvent molecules (except the hydrogen-bonded THF), and the counterion are omitted for clarity. (b) Zero-field ${ }^{57} \mathrm{Fe}$ Mössbauer spectra of 3 (top) and 4 (bottom) collected at $90 \mathrm{~K}: \delta=0.68 \mathrm{~mm} \mathrm{~s}{ }^{-1},\left|\Delta E_{\mathrm{Q}}\right|=$ $0.88 \mathrm{~mm} \mathrm{~s}^{-1}$ for 3 and $\delta=1.01 \mathrm{~mm} \mathrm{~s}^{-1},\left|\Delta E_{\mathrm{Q}}\right|=3.02 \mathrm{~mm} \mathrm{~s}^{-1}$ for 4 . (c) EPR spectrum of 7 (X-band, $9.3298 \mathrm{GHz}$ ) in a 2-methyltetrahydrofuran glass at $4 \mathrm{~K}$ (red) and simulated spectrum (black). 
by a combination of computational and magnetometry studies; specifically, increased Mayer bond orders (from 0.811 in diferrous 3 to 0.947 in diferric 6 , Table $S-6 \dagger$ ), enhanced orbital overlap in the unrestricted corresponding orbitals in 6 compared to 3 (Tables S-8 and S-9†), and an increased exchange coupling constant upon oxidation to the diferric state (Table 1, Fig. S-24 and S-26†) are observed. Taking into account the previous comparison between $\mathbf{3}$ and $\mathbf{3 a}$, the covalency of the $\mathrm{Fe}-\mathrm{O}$ interactions are not governed solely by the geometry of the linkage, but rather are largely dictated by the electrophilicity of the iron sites within the $\mathrm{Fe}_{2}(\mu-\mathrm{O})$ unit. As such, the oxo moiety is more basic in 3a than $\mathbf{3}$ due to THF ligation diminishing the iron electrophilicity, and is more basic in $\mathbf{3}$ than $\mathbf{6}$ due to lower iron electrophilicity in the more reduced molecular oxidation state.

The foregoing results should be compared with the analysis of the relationship between the $\mathrm{Fe}-\mathrm{O}-\mathrm{Fe}$ angle, $\mathrm{Fe}-\mathrm{O}$ covalency, and basicity for diiron(III) oxo complexes put forth by Solomon and coworkers. ${ }^{3,42}$ In Solomon's studies, enhanced basicity is observed with a more acute $\mathrm{Fe}-\mathrm{O}-\mathrm{Fe}$ angle due to a reduction in the $\mathrm{Fe}-\mathrm{O}$ orbital overlap, thereby resulting in pronounced electron density on the bridging oxide ligand when examining an isovalent series. ${ }^{3,42}$ Further comparison with other diiron $\mu$ oxo complexes corroborates this relationship, as a diiron(III) $\mu$ oxo synthesized by Houser and coworkers $^{\mathbf{1 0}}(\angle \mathrm{Fe}-\mathrm{O}-\mathrm{Fe}$ $\left.143.71(10)^{\circ}, \mathrm{p} K_{\mathrm{a}} 21.3(1)\right)$ is several orders of magnitude more basic than 6 ( $\left.\angle \mathrm{Fe}-\mathrm{O}-\mathrm{Fe} 167.1(3)^{\circ}, \mathrm{p} K_{\mathrm{a}}-1.8(6)\right)$ (Table 1); whereas an example by Grapperhaus and coworkers ${ }^{43}$ with similar core metrics to $6\left(\angle \mathrm{Fe}-\mathrm{O}-\mathrm{Fe} 168.47(13)^{\circ}, \mathrm{p} K_{\mathrm{a}} 6.1(3)\right)$ is less basic than the Houser example. The Grapperhaus example is more basic than $\mathbf{6}$, which can be attributed to differences in coordination geometry; the tetrahedral iron sites in 6 are influenced more by the enhanced covalency to the oxo moiety (due to the increased iron electrophilicity) than the octahedrally coordinated iron sites in the Grapperhaus example. ${ }^{43}$

\section{Synthesis and characterization of a mixed-valent diiron $\mu$ - oxo}

Further exploration of the redox chemistry of the diiron $\mu$-oxo complexes studied herein was pursued. A cyclic voltammogram of 6 measured in THF revealed a quasi-reversible reduction event at $-861 \mathrm{mV}$ versus $\left[\mathrm{Cp}_{2} \mathrm{Fe}\right]^{+/ 0}$ (Fig. S-20-S-22†). The peakto-peak separation for this event varies as a function of scan rate, possibly indicating slow electron transfer rate constants. At slower scan rates, i.e. $0.02 \mathrm{~V} \mathrm{~s}^{-1}$, the peak current for oxidation decreases and the redox event becomes irreversible. Nevertheless, these data suggest that a mixed-valent $\mu$-oxo complex is chemically accessible.

The redox chemistry of $\mathbf{6}$ was further explored by using chemical reductants. $\mathrm{Cp}_{2} \mathrm{Co}$ (exhibiting a reduction potential of $-1.33 \mathrm{mV}$ versus $\left[\mathrm{Cp}_{2} \mathrm{Fe}\right]^{+/ 0}$ in dichloromethane ${ }^{44}$ ) was employed to reduce $\mathbf{6}$. Treatment of 6 with one equivalent of cobaltocene in THF for ten minutes affords $\left[\mathrm{Cp}_{2} \mathrm{Co}\right]\left[\left({ }^{t \mathrm{Bu}} \mathrm{dmx}\right) \mathrm{Fe}_{2}(\mu-\mathrm{O}) \mathrm{Cl}_{2}\right](7)$. A frozen solution EPR spectrum collected at $4 \mathrm{~K}$ displays a pseudo-axial signal with features at $g=1.97$, and 1.77 consistent with an $S=1 / 2$ spin state (Fig. 2c). Antiferromagnetic coupling of high-spin ferric $(S=5 / 2)$ and ferrous $(S=2)$ centers in 7 explains the doublet spin state and supports the formation of a mixed-valent diiron bridging oxo complex. X-ray diffraction studies on single crystals of 7 obtained from a concentrated THF solution at $70{ }^{\circ} \mathrm{C}$ unveiled two crystallographically distinct iron sites (Fig. 1b); two distinct sites were further observed by ${ }^{57}$ Fe Mössbauer spectroscopy, the parameters of which support one center being more consistent with a high spin $\mathrm{Fe}^{\mathrm{II}}$ and the other as a high spin $\mathrm{Fe}^{\mathrm{III}}$ center (Fig. S-8 and S-9†). The $\mathrm{Fe}-\mathrm{O}$ bond distances in 7 (1.8034(15) $̊, 1.8928(15) \AA)$ are longer than those in both diferrous 3 and diferric 6 , and the difference of $0.09 \AA$ indicates a potentially localized nature. The $\mathrm{Fe}-\mathrm{O}-\mathrm{Fe}$ angle of $148.98(10)^{\circ}$ resides in between the fairly linear $\mathrm{Fe}-\mathrm{O}-\mathrm{Fe}$ vector in the diferric state $\left(167.1(3)^{\circ}\right)$ and the significantly more acute $\mathrm{Fe}-\mathrm{O}-\mathrm{Fe}$ angle of the diferrous complex $\left(116.00(14)^{\circ}\right)$.

\section{Reactivity of the mixed-valent diiron $\mu$-oxo}

Upon synthesizing the mixed-valent oxo complex 7 via the method previously described, ${ }^{1} \mathrm{H}$ NMR and ${ }^{57} \mathrm{Fe}$ Mössbauer spectroscopies reveal the formation of 7 together will a small amount of hydroxide 5 . While 7 is stable at $70{ }^{\circ} \mathrm{C}$ for 12 hours and does not react with weak $\mathrm{C}-\mathrm{H}$ bonds (such as those in 1,4cyclohexadiene), this mixed valent species is protolytically sensitive. Addition of one equivalent of water to 7 leads to

Table 1 Comparison of diron $\mu$-O complexes studied herein with previously studied examples

\begin{tabular}{|c|c|c|c|c|c|c|c|}
\hline Complex & Fe-O distances $(\AA)$ & $\mathrm{Fe}-\mathrm{O}-\mathrm{Fe}$ angle $\left(^{\circ}\right)$ & Fe-Fe distance $(\AA)$ & $\begin{array}{l}\mathrm{p} K_{\mathrm{a}} \text { of } \\
\text { conjugate acid }\end{array}$ & $J_{\text {calc }}\left(\mathrm{cm}^{-1}\right)$ & $J_{\exp }\left(\mathrm{cm}^{-1}\right)$ & Reference \\
\hline 3 & $1.7939(14)$ & $116.00(14)$ & $3.0425(10)$ & $15.3(6)$ & -65.9 & -53.2 & This work \\
\hline $3 \mathbf{a}^{a}$ & $1.858,1.859$ & 126.281 & 3.315 & $26.8(6)$ & -69.3 & - & This work \\
\hline 6 & $1.7734(10)$ & $167.1(3)$ & $3.5244(17)$ & $-1.8(6)$ & -96.4 & -122 & This work \\
\hline$\left(\mathrm{Fe}^{\mathrm{II}}\right)_{2}(\mu-\mathrm{O})^{b}$ & $1.7503(4)$ & $167.55(14)$ & $3.4831(4)$ & - & $\sim-200$ to -250 & - & 22 \\
\hline$\left(\mathrm{Fe}^{\mathrm{II}}\right)_{2}(\mu-\mathrm{O})^{c}$ & $1.784(9)$ & $174.7(4)$ & $3.573(9)$ & - & - & - & 21 \\
\hline$\left(\mathrm{Fe}^{\mathrm{II}}\right)_{2}(\mu-\mathrm{O})^{d}$ & $1.753(2)$ & $147.7(3)$ & $3.367(3)$ & - & - & - & 21 \\
\hline$\left(\mathrm{Fe}^{\mathrm{III}}\right)_{2}(\mu-\mathrm{O})^{e}$ & $1.8194(16), 1.8156(16)$ & $143.71(10)$ & $3.4542(7)$ & $21.3(1)$ & - & -87.5 & 10 \\
\hline$\left(\mathrm{Fe}^{\mathrm{III}}\right)_{2}(\mu-\mathrm{O})^{f}$ & $1.791(2), 1.803(2)$ & $168.47(13)$ & $3.5763(6)$ & $6.1(3)$ & - & - & 43 \\
\hline
\end{tabular}

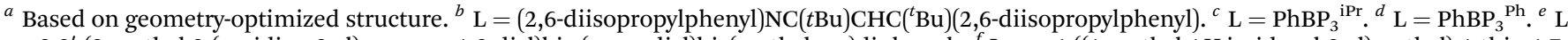

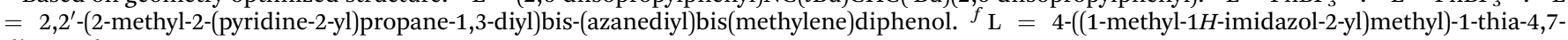
diazacyclononane. 
immediate consumption of 7 and quantitative formation of $\left[\mathrm{Cp}_{2} \mathrm{Co}\right]\left[\left({ }^{\mathrm{tBu}} \mathrm{dmx}\right) \mathrm{Fe}_{2}(\mu-\mathrm{OH}) \mathrm{Cl}_{2}\right] \quad(\mathbf{5 d}) .^{45}$ We were not able to unequivocally determine the origin of the reducing equivalent which reduces a potential mixed-valent hydroxide intermediate species to diferrous $\mathbf{5}$, but the hydroxide generated upon proton transfer to 7 could act as a potential reductant. Alternatively, 7 can be converted to $\left[\mathrm{Cp}_{2}{ }^{*} \mathrm{Co}\right]\left[{ }^{t \mathrm{Bu} \mathrm{dmx}\}} \mathrm{Fe}_{2}(\mu-\mathrm{O}) \mathrm{Cl}_{2}\right](\mathbf{5 c})$ by addition of one equivalent of decamethylcobaltocene. These reactions demonstrate the intricate interplay between oxidation and protonation state.

Lastly, we were able to evaluate the strength of the $\mathrm{O}-\mathrm{H}$ bond in $\left[\mathrm{Et}_{4} \mathrm{~N}\right]\left[\left({ }^{\mathrm{Bu}} \mathrm{dmx}\right) \mathrm{Fe}_{2}(\mu-\mathrm{OH}) \mathrm{Cl}_{2}\right](\mathbf{5 b})$ by addition of 2,4,6-tri-tertbutylphenoxyl radical as a hydrogen atom acceptor. Slow generation of 7 is observed upon addition of 2,4,6-tri-tertbutylphenoxyl radical to 5 (Fig. S-19†), suggesting that the BDEs of the $\mathrm{O}-\mathrm{H}$ bond of $\mathbf{5}$ and 2,4,6-tri-tert-butylphenol are comparable. $^{46}$

\section{Conclusions}

The Pacman ligand platform ${ }^{t \mathrm{Bu}} \mathrm{dmxH}_{2}$ was selected as a template for the synthesis of dinuclear iron complexes. Reaction of ${ }^{\mathrm{tBu}} \mathrm{dmxH}_{2}$ with $\mathrm{Fe}_{2}(\mathrm{Mes})_{4}$ affords a diiron complex 1 that is an excellent starting material for the introduction of bridging oxygen atoms. Our results indicate that the ${ }^{t \mathrm{Bu}} \mathrm{dmxH}_{2}$ ligand serves as a preorganized scaffold to support a diiron core but is sufficiently flexible to allow for moderate structural rearrangements.

Importantly, we demonstrate that this ligand platform supports a diiron core in multiple oxidation states. As such, this system provided us with the unique opportunity to compare the reactivity of a series of diiron $\mu$-oxo complexes in a similar coordination environment. We showcase that the diiron species have a distinct inherent preference for oxo or hydroxide bridge formation, similar to bimetallic iron enzymes in nature. ${ }^{1-4}$ While a diferrous, a mixed-valent, and a diferric $\mu$-oxo complex could be isolated, oxidized bridging hydroxide complexes remained elusive. The acidity of the bridging hydroxide increases substantially upon oxidation $\left(\mathrm{p} K_{\mathrm{a}}\right.$ of $\left.\mathbf{6 a}=-1.8(6)\right)$, which precludes isolation of a diferric bridging hydroxide. Similarly, the basicity of the bridging oxygen atom increases upon reduction $\left(\mathrm{p} K_{\mathrm{a}}\right.$ of $\left.3 \mathbf{a}=15.3(6)\right)$ and even further upon coordination of neutral $\left(\mathrm{p} K_{\mathrm{a}}\right.$ of $\mathbf{4}=$ $26.8(6)$ ) or anionic ligands ( $\mathrm{p} K_{\mathrm{a}}$ of $\mathbf{5}$ is expected to be greater than 26.8).

The primary influence of changing the $\mathrm{Fe}-\mathrm{O}-\mathrm{Fe}$ bonding and, thus, its attendant covalency is the relative electrophilicity of the Fe sites within that unit. Whereas solvation of the $\left[\mathrm{Fe}_{2}(\mu-\right.$ O)] core results in a substantial increase of the oxo basicity relative to 3 , anation leads to oxo protonation without a discernible intermediate. Solvation and anation electrostatically reinforce the iron centers, diminishing the $\mathrm{Fe}-\mathrm{O}$ interaction and increasing oxo basicity. Oxidation of diferrous 3 to diferric 6, on the other hand, leads to an increased covalent interaction as the iron sites are now more electrophilic following oxidation. Consequently, the oxo moiety is far less basic in the higher oxidation state complex.
Finally, we were able to isolate a rare mixed-valent diiron $\mu$ oxo complex and observed a decomposition pathway distinct from previously reported mechanisms. Rapid disproportionation of a mixed-valent diiron oxo complex to a diferrous hydroxide together with a diferric $\mu$-oxo complex has been described in the literature. ${ }^{10}$ In our system, decomposition of the mixed-valent complex proceeds cleanly to diferrous hydroxide 5 without the formation of a diferric species. We believe that the reactivity showcased by the diiron complexes presented herein complements current mechanistic understanding and work is underway to elucidate the reactivity of these complexes with dioxygen.

\section{Conflicts of interest}

There are no conflicts to declare.

\section{Acknowledgements}

This work was supported by a grant from the NIH (GM-115815), the Dreyfus Foundation (Teacher-Scholar Award to T. A. B.), and Harvard University. E. J. J. is grateful for an NSF Predoctoral Fellowship; C. K. was supported by the Jacques-Emile Dubois Graduate Student Dissertation Fellowship Fund; and R. A. M. is grateful for postdoctoral support from the European Union's Horizon 2020 Research and Innovation Programme under grant agreement No. 752684. The authors would like to thank Diana Iovan for helpful discussions regarding calculations.

\section{Notes and references}

1 L. Que and A. E. True, Dinuclear Iron- and Manganese-Oxo Sites in Biology, in Progress in Inorganic Chemistry, John Wiley \& Sons, Inc., 2007, pp. 97-200, DOI: 10.1002/ 9780470166390.ch3.

2 B. J. Wallar and J. D. Lipscomb, Chem. Rev., 1996, 96, 26252658.

3 E. I. Solomon, T. C. Brunold, M. I. Davis, J. N. Kemsley, S.-K. Lee, N. Lehnert, F. Neese, A. J. Skulan, Y.-S. Yang and J. Zhou, Chem. Rev., 2000, 100, 235-350.

4 J. B. Vincent, G. L. Olivier-Lilley and B. A. Averill, Chem. Rev., 1990, 90, 1447-1467.

5 H. Thomann, M. Bernardo, J. M. McCormick, S. Pulver, K. K. Andersson, J. D. Lipscomb and E. I. Solomon, J. Am. Chem. Soc., 1993, 115, 8881-8882.

6 V. J. DeRose, K. E. Liu, D. M. Kurtz, B. M. Hoffman and S. J. Lippard, J. Am. Chem. Soc., 1993, 115, 6440-6441.

7 S. Friedle, E. Reisner and S. J. Lippard, Chem. Soc. Rev., 2010, 39, 2768-2779.

8 U. Bossek, H. Hummel, T. Weyhermüller, E. Bill and K. Wieghardt, Angew. Chem., Int. Ed., 1996, 34, 2642-2645.

9 J. A. R. Hartman, R. L. Rardin, P. Chaudhuri, K. Pohl, K. Wieghardt, B. Nuber, J. Weiss, G. C. Papaefthymiou, R. B. Frankel and S. J. Lippard, J. Am. Chem. Soc., 1987, 109, 7387-7396. 
10 A. Jozwiuk, A. L. Ingram, D. R. Powell, B. Moubaraki, N. F. Chilton, K. S. Murray and R. P. Houser, Dalton Trans., 2014, 43, 9740-9753.

11 W. H. Armstrong and S. J. Lippard, J. Am. Chem. Soc., 1984, 106, 4632-4633.

12 K. S. Murray, Coord. Chem. Rev., 1974, 12, 1-35.

13 D. M. Kurtz, Chem. Rev., 1990, 90, 585-606.

14 E. Y. Tshuva and S. J. Lippard, Chem. Rev., 2004, 104, 9871012.

15 R. Shakya, D. R. Powell and R. P. Houser, Eur. J. Inorg. Chem., 2009, 2009, 5319-5327.

16 W. H. Armstrong, A. Spool, G. C. Papaefthymiou, R. B. Frankel and S. J. Lippard, J. Am. Chem. Soc., 1984, 106, 3653-3667.

17 R. E. Norman, S. Yan, L. Que, G. Backes, J. Ling, J. SandersLoehr, J. H. Zhang and C. J. O'Connor, J. Am. Chem. Soc., 1990, 112, 1554-1562.

18 J. Rosenthal, T. D. Luckett, J. M. Hodgkiss and D. G. Nocera, J. Am. Chem. Soc., 2006, 128, 6546-6547.

19 F. Arena, C. Floriani, A. Chiesi-Villa and C. Guastini, J. Chem. Soc., Chem. Commun., 1986, 1369-1371.

20 S. C. Payne and K. S. Hagen, J. Am. Chem. Soc., 2000, 122, 6399-6410.

21 C. T. Saouma, C. C. Lu, M. W. Day and J. C. Peters, Chem. Sci., 2013, 4, 4042-4051.

22 N. A. Eckert, S. Stoian, J. M. Smith, E. L. Bominaar, E. Münck and P. L. Holland, J. Am. Chem. Soc., 2005, 127, 9344-9345.

23 J. D. Cohen, S. Payne, K. S. Hagen and J. Sanders-Loehr, J. Am. Chem. Soc., 1997, 119, 2960-2961.

24 S. K. Ghosh and S. P. Rath, J. Am. Chem. Soc., 2010, 132, 17983-17985.

25 S. L. Daifuku, J. L. Kneebone, B. E. R. Snyder and M. L. Neidig, J. Am. Chem. Soc., 2015, 137, 11432-11444.

26 A. M. Tondreau, C. Milsmann, A. D. Patrick, H. M. Hoyt, E. Lobkovsky, K. Wieghardt and P. J. Chirik, J. Am. Chem. Soc., 2010, 132, 15046-15059.

27 H. Andres, E. L. Bominaar, J. M. Smith, N. A. Eckert, P. L. Holland and E. Münck, J. Am. Chem. Soc., 2002, 124, 3012-3025.
28 R. Karlsson, J. Chem. Eng. Data, 1973, 18, 290-292.

29 E. R. King, E. T. Hennessy and T. A. Betley, J. Am. Chem. Soc., 2011, 133, 4917-4923.

30 I. Nieto, F. Ding, R. P. Bontchev, H. Wang and J. M. Smith, J. Am. Chem. Soc., 2008, 130, 2716-2717.

31 F. Ding, J. M. Smith and H. Wang, J. Org. Chem., 2009, 74, 2679-2691.

32 I. Mayer, Chem. Phys. Lett., 1983, 97, 270-274.

33 I. Mayer, Int. J. Quantum Chem., 1984, 26, 151-154.

34 W.-L. Man, W. W. Y. Lam, S.-M. Yiu, T.-C. Lau and S.-M. Peng, J. Am. Chem. Soc., 2004, 126, 15336-15337.

35 N. S. Venkataramanan and S. Rajagopal, Tetrahedron, 2006, 62, 5645-5651.

36 R. E. Cowley, N. A. Eckert, S. Vaddadi, T. M. Figg, T. R. Cundari and P. L. Holland, J. Am. Chem. Soc., 2011, 133, 9796-9811.

37 M. T. Green, J. H. Dawson and H. B. Gray, Science, 2004, 304, 1653-1656.

38 C. V. Sastri, J. Lee, K. Oh, Y. J. Lee, J. Lee, T. A. Jackson, K. Ray, H. Hirao, W. Shin, J. A. Halfen, J. Kim, L. Que, S. Shaik and W. Nam, Proc. Natl. Acad. Sci. U. S. A., 2007, 104, 19181-19186.

39 K. A. Prokop, S. P. de Visser and D. P. Goldberg, Angew. Chem., Int. Ed., 2010, 49, 5091-5095.

40 K. L. Stone, L. M. Hoffart, R. K. Behan, C. Krebs and M. T. Green, J. Am. Chem. Soc., 2006, 128, 6147-6153.

41 R. M. Theisen, J. Shearer, W. Kaminsky and J. A. Kovacs, Inorg. Chem., 2004, 43, 7682-7690.

42 C. A. Brown, G. J. Remar, R. L. Musselman and E. I. Solomon, Inorg. Chem., 1995, 34, 688-717.

$43 \mathrm{~J} . \quad$ Cui, M. S. Mashuta, R. M. Buchanan and C. A. Grapperhaus, Inorg. Chem., 2010, 49, 10427-10435.

44 N. G. Connelly and W. E. Geiger, Chem. Rev., 1996, 96, 877910.

45 J. M. Carroll and J. R. Norton, J. Am. Chem. Soc., 1992, 114, 8744-8745.

46 Y.-R. Luo, Handbook of Bond Dissociation Energies in Organic Compounds, CRC Press LLC, Boca Raton, FL, 2003. 